Article

\title{
New Horizons? Comparisons and Frames of Reference of Polish Multiple Migrants Worldwide
}

\author{
Justyna Salamońska * and Aleksandra Winiarska
}

Centre of Migration Research, University of Warsaw, 02-093 Warsaw, Poland; E-Mails: jj.salamonska@uw.edu.pl (J.S.), aa.winiarska@uw.edu.pl (A.W.)

* Corresponding author

Submitted: 21 September 2020 | Accepted: 3 November 2020 | Published: 18 February 2021

\begin{abstract}
Building on the literature on transnational social fields (Levitt \& Glick Schiller, 2004) and the research agenda on pluri-local transnational studies (Pries, 2001), in this article we examine the processes of Polish migrants' social positioning. Nowadays many migrant trajectories are more complex than moving just from one place to another, involving repeated migration spells, returns, and onward mobility. In particular, multiple migration routes involving more than one destination expand the horizons lived by migrants and hence the frames in which they can position themselves. We adopt an actor-centred approach to better understand how highly mobile individuals negotiate social comparisons concerning the contexts they have engaged in during their multiple migration spells. This article draws on qualitative data from the MULTIMIG project that examines Polish migration worldwide. The analysis is based on a qualitative panel study with 70 Poles living abroad, who have the experience of multiple migration (who have lived in two countries outside of Poland for at least three months in each). The interviews shed light on how Polish migrants make social comparisons, and in particular, which frames of reference they adopt.
\end{abstract}

\section{Keywords}

frames of reference; multiple migrants; Polish migrants; social positioning

\section{Issue}

This article is part of the issue "Migration and Unequal Social Positions in a Transnational Perspective" edited by Thomas Faist (Bielefeld University, Germany).

(C) 2021 by the authors; licensee Cogitatio (Lisbon, Portugal). This article is licensed under a Creative Commons Attribution 4.0 International License (CC BY).

\section{Introduction}

The concept of social comparison has evolved in the social science literature, from being understood as a human need, a source of knowledge about individual strengths and weaknesses to putting more focus on the tendency to evaluate, used by individuals to increase their positive self-image, especially via downward comparisons (White, 2012). Adopting a transnational lens adds some new questions to the analysis of social positioning, concerning, inter alia, the reference frames used for social comparisons. Transnationality, with its potential of simultaneous membership in different countries, offers a broader, comparative cross-border framework for such comparisons
(Faist, 2014; Levitt \& Glick Schiller, 2004). At the simplest, migrants can assess their similarities and differences compared to those who are not mobile (both in the country of origin and destination) or to other mobiles, both from their own migrant community and others. These sets of comparisons may further extend for those who wish to move further, to onward destinations, measuring current life chances against those expected in the subsequent stopping place. Last but not least, social comparisons can extend beyond the places of origin and destination, towards supranational and global perspectives. It is these different frames of reference used for comparisons with regard to locations and social relations that we are mostly interested in here. 
In the article, we present some results from the MULTIMIG project, a unique study of Polish multiple migrants (people who have lived in at least two different countries abroad). The project is aimed at tracking the international trajectories and personal experiences of these Poles. The empirical material comes from two waves of semi-structured interviews conducted within a qualitative panel study (QPS). The interviewees have collected life experiences and built social networks across several contexts, potentially making them 'comparative experts,' drawing on resources of past international mobility. Hence, we ask: What kind of comparisons do Polish multiple migrants make? What are the most explicit dimensions of these comparisons? In the following sections, we look at different frames of reference and social comparisons made in relation to various significant others-embedded in different socio-spatial contexts. We explore the notion of 'normality' in the context of mobility, move on to imposed comparisons versus personal aspirations and finally acknowledge the global power dynamics and reference frames noticeable in Polish multiple migrants' narratives.

\section{Social Comparisons, Frames of Reference and Multiple Migration}

\subsection{From Sedentary to Mobile Lens in Migration Studies}

Already in the 1990s, Malkki (1992), analysing the dominant discourse in migration and refugee studies, wrote about "a powerful sedentarism in our thinking" (p. 31), taken for granted and going almost unnoticed. Others, including de Haan (1999), Scalettaris (2007) and Ghorashi (2017), followed with the sedentary bias criticism. Sheller and Urry (2006) broadened this sedentary diagnosis to 'a-mobile' social science more generally. In particular, Urry's (2000) contribution was to push the static-versus-mobile debate towards a focus on the latter. His work has, in many aspects, been eye-opening, highlighting some less-studied phenomena. He used the example of automobilities, along with mass international travel, to describe corporeal mobilities. Urry underlined that not only people travel but objects as well, including consumer goods and values associated with them. The Internet and popular TV, in turn, open possibilities for 'imaginative travel.' The 'mobilities turn' in the social sciences carefully re-directed our attention elsewhere, to all these different and multi-directional flows making up social life.

Although literature on migration and mobilities is rarely brought together (see, e.g., Moret, 2017), migration literature to some extent recognises this 'mobile' element, especially in the analyses of non-permanent, temporary migration (for an overview see Górny \& Kindler, 2016) and even 'liquid' migration (Engbersen, Snel, \& de Boom, 2010) or so-called 'enfolded mobilities' (Williams, Chaban, \& Holland, 2011), including visiting friends and relatives (Williams \& Hall, 2000). The virtual mobility of migrants has been occupying the research agenda for quite some time now, as migrants seem to be the most natural Information and Communication Technology (ICT) users, which are often indispensable for them to stay in touch with friends and family elsewhere (in relation to Polish migrants see, e.g., Bell, 2016; Burrell, 2011). Other parts of the literature, however, remain predominantly focused on migration as a onetime move turning into long-term settlement in the destination country and its resulting processes of migrant integration into various spheres of society.

\subsection{Social Comparisons: From Binary to Broader and Multi-Faceted Frames of Reference}

Traditional research on migration has not only studied how people move along two-way corridors between the place of origin and destination but also how comparisons made by migrants are locked within these two contexts. In studies of labour market incorporation, Piore's (1979) birds of passage were understood to accept working in the secondary labour market of their destination country because the main point of reference for them was the place of origin. The dual frame of reference described by Waldinger and Lichter (2003) looked at migrants assessing their conditions in the destination by standards they knew from the origin. Similarly, in analyses of social inequalities and social protection, the main comparisons drawn seem to refer to "relative (dis)advantage" between places of origin and residence (Faist \& Bilecen, 2015, p. 290, emphasis in original). International migration can entail migrants' upward or downward social mobility from origin to destination, or both, as in "contradictory class mobility," referring to financial and occupational status (Parreñas, 2015 , p. 26). A study by Nowicka (2013), drawing on work by Bourdieu (the notion of capital) and Hradil (the concept of social position), draws attention to the directions of social positioning among Polish entrepreneurs in Germany. Nowicka distinguishes between three directions of migrant social positioning (single space, bi-local, overlapping) as well as migrant connections to localities and social networks. Additionally, her analysis is dynamic, allowing the tracking of shifts in social statuses along the migration trajectory. These transnational social positionings, however, are locked into the origin (Poland) and destination (Germany) binary. One case in particular, the trajectory of a Polish entrepreneur in Germany who regularly carries out construction work in Italy and Austria, raises questions about broader frames of reference and the possible impact of capital flows from multiple countries on individual social positioning.

Hence, we turn to transnational literature which has embraced how migrants' lives are embedded in multilayered and multi-sited transnational fields (Levitt \& Glick Schiller, 2004). Levitt and Glick Schiller highlight the simultaneity of migrant incorporation in the destination and the concurrent keeping of transnational connections 
to family and friends at the place of origin and elsewhere, with the social field defined as "a set of multiple interlocking networks of social relationships through which ideas, practices, and resources are unequally exchanged, organised, and transformed" (Levitt \& Glick Schiller, 2004, p. 1009). Direct and indirect connections which cross borders become transnational. Pries (2001) pushes this concept of transnational social space even further to explicitly recognise how it may be 'pluri-local,' in particular in the ever-growing presence of new ICT and mass migration. However, what Pries proposes is not exactly a well-defined paradigm but rather a research agenda for studying social realities consisting of practices, artefacts and symbols, which still seems to be an underdeveloped approach in the study of international migration. With a pluri-local focus on individuals who have moved repeatedly to various destinations, the horizons for comparisons seem to broaden, and we focus on these comparisons especially concerning social relations and locations in which these relations are based.

Research on migrant domestic workers highlights how mobile individuals measure and compare the pros and cons of various places, ranking them one against another (Parreñas, 2015; Paul, 2017). Paul (2017) describes cognitive maps of the world made up by her informants, which give a sense of how they select future destinations and reflect their desire for upward social mobility. Predominantly female Indonesian and Filipino domestic workers remain on the move while bound by limited sets of resources in this highly mobile labour market segment. The mappings of multiple locations involve considerations of social mobility (see Fielding, 1993, writing about escalator regions) with escalator effects referring also to various life spheres beyond economic factors, including lifestyle and self-confidence (see King, Lulle, Parutis, \& Saar, 2018). Favell (2008) described the 'social spiralism' of migrants regarding blocked opportunities back at home. Movers in the European Union, particularly women, take the risk of jumping on the 'escalator' and building an alternative life project to the wellstructured and predictable life trajectory of those left behind at their place of origin.

Related to the above discussion is the notion of 'mobility capital' (introduced by Moret, 2017) as a new element of social differentiation. Drawing on the case of Somali migrants, Moret exemplifies how mobility capital is made up of both past mobility experiences as well as the potential for future mobility and how it can be converted into other forms of capital. It is also a way through which migrants can negotiate divergent social positions in the place of origin and, more broadly, in Europe, since the mobility capital concept transcends single nation-state borders and provides a focus lens on social inequalities in transnational perspective. In particular, Moret draws attention to the movers' race, ethnicity and religion in the context of global inequalities, and the consequent vulnerability of rights. Representation or experience of movement by Blacks and Muslims will differ from the privilege of cross-border mobility of white Europeans.

Another facet of the power relations in Europe has long been the symbolic dichotomy between 'East' and 'West' which is in itself a socio-cultural construct sustained through discursive practices and social imaginaries (according to Buchowski, 2006, as cited in Manolova, 2020, p. 522; see also, e.g., Lulle, King, Dvorakova, \& Szkudlarek, 2019). Migration originating from postsocialist countries, driven by experiences both of material deprivation and limited social rights may highlight a relative disadvantage in comparison to places perceived as better-developed in this respect. This, in turn, can lead to defining a desirable 'normality' in the destination, based on comparisons with one's situation in the past outside of the present country of residence (see, e.g., Galasińska \& Kozłowska, 2009; McGhee, Heath, \& Trevena, 2012). Also, as mobilities may involve lifestyle as well as work-related choices (Krings, Moriarty, Wickham, Bobek, \& Salamońska, 2013), these comparisons may be made on various material as well as non-material dimensions. The notion of 'normality' has been explored in the literature concerning migration from Poland and other Central and Eastern European countries. It has been developed as a normative concept, where 'normal' life is associated with, to quote Manolova (2019, p. 78):

i) a sense of stability and order that makes life predictable and controllable; ii) a basic level of social and moral justice, which implies a dignified life for every individual regardless of their identity, belonging or connections; and iii) a dignified status of labour....

In other words, the concept of 'normality' is related to seeking comfort both in the economic sphere, where one can afford a preferable lifestyle, and in the socio-public sphere, where one can express their preferred identity (Polkowski, 2017).

\subsection{Why Research Comparisons and Frames of Reference Used by Multiple Migrants from Poland?}

In this article, we focus on multiple migrants whom we define as persons who have moved internationally more than once to more than one destination. Sequences of multiple migrations may differ, involving a series of onward and return migrations (to the place of origin or a previous destination). Multiple migration can also involve short and/or long term spells, and various geographies, like intra- or inter-continental (Salamońska, 2017). Among multiple migrants we can find movers holding various sets of resources, those migrating at the bottom (Paul, 2017) or at the top of the labour market (Beaverstock, 2005; Bhachu, 1985). For these different groups, migration may lead to upward social mobility (on 'escalator migration' see Hugo, 2008; on 'stepwise migration' see Paul, 2017) or constitute a career development strategy (Beaverstock, 2005). What is more, research 
on international students highlights how the aspiration for onward movement after graduation may be linked not only to global career prospects but also to selfexploration and personal development, as well as a feeling that they could fit in anywhere (Wu \& Wilkes, 2017). While a highly differentiated group in terms of their motivations and international trajectories, multiple migrants offer an interesting case to explore more deeply the social comparisons at work across multiple national contexts. First, they can potentially provide more evidence on a wider variety of frames of reference. Faist and Bilecen (2015), in their analysis of social positionings and social inequalities in transnational spaces, enumerate possible frames of reference, from the emigration and immigration side to onward destinations and global perspectives. As we add the pluri-locality lens, we understand social comparisons as made and remade between past and present, highlighting different places and meanings associated with them (see also Ghorashi, 2017).

We focus on migration from Poland, acknowledging the socio-political context of the country of origin and the broader region, which is Central Eastern European/post-socialist space. This specific context may influence migrants' aspirations and their perceptions of desirable outcomes that drive mobility in certain directions-most often 'the West' (Drinkwater \& Garapich, 2015; Kaźmierska, Piotrowski, \& Waniek, 2011; Manolova, 2020). After the fall of the 'iron curtain,' Poland has been undergoing political and economic transition since 1989 and joining the European Union in 2004 resulted in mass migration moves to other member states of 'old' Europe due to free-movement rights and the opening of labour markets (Grabowska-Lusińska \& Okólski, 2009; Lulle et al., 2019). To date, many people perceive the labour market, welfare and lifestyle opportunities accessible in these countries as a desirable goal-in reference to the concept of 'normality' evoked earlier in this text. This agrees with the notion of European 'mental space' which "provides horizons of competitive or emulative comparison between achievements in terms of the standard of living in different European nations and in terms of chances for biographical plans and undertakings" (Fritz Schutze, as cited in Kaźmierska et al., 2011, p. 141). The economic recession of 2008 did not impact so greatly on emigration from Poland (the country was largely spared the economic crisis) but it did have effects on those Polish migrants who were already resident in the European destinations affected by the recession, triggering some return and onward mobility (Krings et al., 2013).

For the analyses in this article, Poland matters as a place of origin of migrants, but we also draw attention to the specific places of settlement along the migration trajectory along with 'structures and opportunities' present in these local contexts (Bivand Erdal \& Ryan, 2018). We take as the case study Polish multiple migrants because they allow tracking of a heterogeneous group in terms of socio-economic status, resources possessed, migration motivations and trajectories of mobility spanning across countries. This diversity of individual characteristics and destinations provides a good starting point for probing about comparisons and frames of reference.

\section{Data and Methods}

This article draws on qualitative data from the MULTIMIG project "In Search of a Theory of Multiple Migration. A Quantitative and Qualitative Study of Polish Migrants after 1989" that examines Polish migration worldwide via three waves of interviews of a QPS. The QPS started in 2018 (wave one) with semi-structured interviews with Poles living abroad who have the experience of multiple migrations (i.e., people born in Poland who have lived in at least two countries outside of Poland for three months or more in each). Wave two was conducted in 2020 and wave three is planned for 2021. The interviews conducted up to date shed light on how Polish migrants make social comparisons and, in particular, what frames of reference they mention when making sense of their international trajectories so far as well as future plans.

MULTIMIG followed a purposive sampling strategy aiming to collect a variety of experiences from males and females at various points in their life course, with different levels of resources (economic, social and cultural capital, education, qualifications and occupations), diverse family situation and different multiple migration trajectories. In this respect, our sample may be described as 'super-diverse' in terms of the complexity of socio-demographic characteristics, location and settlement strategies of Polish migrants (Grzymala-Kazlowska \& Phillimore, 2019). Researchers reached informants via, among others, extended social networks, general use and career-oriented social networking platforms, and expatriate blogs. According to the QPS methodology, subsequent waves of interviews are conducted with the same sample of informants where particular themes are explored repeatedly while others may differ. The main aim of such an approach in migration studies is to capture "change and continuity through time and space" (Winiarska, 2017, p. 5). Wave one of the QPS started in September 2018 with an initial sample of 70 informants. Wave two, which started in December 2019, managed to retain 62 informants out of an initial sample of 70 . Interview length ranged between thirty minutes and two hours and thirty minutes.

There was a fair gender balance in the achieved sample. Among informants, over two-thirds held third-level education. The QPS participants were aged between their early twenties and early sixties and had migrated at various points of their life (majority as adults). Our informants were based in Africa, both Americas, Asia, Australia and New Zealand, but most resided in European countries and had lived in at least two countries outside of Poland. All informants were asked about the other locations they had resided in before the current destination, which in many cases included four, five or 
six different countries, but some highly mobile people were unable to count the actual number of migration spells, as they circulated between these different places. Interviewees had resided in their current countries of settlement for various periods of time-ranging from a few months to decades. Moreover, some had moved from one country to another in between the two waves of MULTIMIG interviews. Reaching such a geographically dispersed sample was possible thanks to Internetmediated research using technologies such as Skype, FaceTime, WhatsApp, Facebook Messenger, Signal or phone (with researchers navigating these tools and multiple time zones). Interviews were conducted in the Polish language. The quotes in the empirical analysis section were translated into English by the authors. Each quote used in this article is accompanied by background information on the QPS participant, including gender, age group and countries lived outside of Poland (if the countries in the migration trajectory were rare destinations for Polish migrants and there was a fair risk of informant's identification, we also anonymised the country namese.g., African countries). All names used when presenting informants' narratives are pseudonyms.

The data presented in this article come from two waves of the on-going QPS, with only synchronic analysis of collected material at this point. The first wave of interviews included questions about migration trajectory, future plans and notion of home. The second wave of interviews inquired about broadly understood change in informant's life since the wave one interviews, additionally covering topics such as travels, social networks and cultural diversity. The analysis offered in this article focuses on the comparisons and frames of reference used by migrants in their narrating of these topics. During the second wave of interviews, we asked about social comparisons that the informants make and who they compare with when thinking of their social position. Many of them found this question difficult and declared that they avoid comparisons altogether (although comparing to others was concurrently perceived as an 'inherent part' of human nature). In many interviews (both first and second wave) themes related to social positioning did, however, appear spontaneously, especially when talking about life satisfaction, plans for the future, and possible life trajectories if migrants had not chosen to move internationally in the first place. We will try to reflect on some of these narratives here to better understand how highly-mobile individuals negotiate social comparisons concerning multiple contexts.

\section{Multi-Faceted Frames of Reference: An Empirical Analysis of Polish Multiple Migrants' Narratives}

Social comparisons often involve complex and multidimensional intrapersonal and interpersonal processes. Their outcome is dependent on the perspective adopted by the actor-e.g., whether based on individual aspirations or group affiliations and whether they are in-group or out-group. Moreover, social positioning will be influenced both by the starting point as well as resources held and acquired at different points of the life course. Some comparisons may be more objective while others appear more fluid and vague, based on material achievements, professional status, lifestyles or personal trajectories, for example. Although multiple migration may be driven by different factors and motives, the mobility itself remains an important point of reference for migrants.

\subsection{Mobile versus Settled: Which is 'the Norm'?}

In our analysis, we aim to unpack the various frameworks adopted by Polish multiple migrants when it comes to processes of social positioning. Our focus will be on different types of comparisons within social relations at different locations involved: to persons settled in the country of origin (Poles living in Poland), to persons settled (sometimes temporarily) in the host country (other Polish migrants, other migrants, both European and non-European, and the host population) as well as wider comparisons that have rarely been taken into consideration in existing literature to date.

When it comes to positioning oneself in relation to stayers in the country of origin, our interviewees made some typical comparisons concerning professional achievements, material status or family situation, which we leave aside as these have been researched more extensively (e.g., Piore, 1979; Waldinger \& Lichter, 2003). A less-explored theme that we found especially interesting was the opposition between being rooted in one place contrary to being on the move from one place to another. The first may give a sense of stability, which mobiles often long for, but on the other hand, multiple migration may allow wider perspectives and opportunities for living a life perceived as more interesting. Our interlocutors reflected on this and positioned themselves in contrast to settled friends, taking into account their own independence and personal experiences. In this case, life trajectories become closely related to lifestyle which becomes an important point of reference when comparing one's position to others. Against a more traditional understanding of 'dual frames of reference,' here what makes a difference is quite intangible, a set of experiences, stories and dreams collected on the way. For example, Bartek, a mobile man in his late twenties, reflects:

And I look at those friends of mine who have graduated from these great universities, making these great careers, but you know, they live in Poland, working in one place, you know, they haven't seen the world too much.....I can tell interesting stories and they...they don't have such interesting stories to tell. (Bartek has lived in the UK, Greece, Ireland and Norway)

Magda, a woman in her late thirties, raises similar issues in comparison to her best friend settled back in Poland: 
My best friend...has a husband and two sons. She has a very good job, she earns a lot of money. So she is very pleased. Sometimes I envy her, that she has been living in one place all the time. All her friends are there, and I have friends in Canada, I have friends in California, Chicago, I have friends in Brazil, Great Britain, all over the world....and I envy that she has everyone in one place, she keeps in touch with everyone. But on the other hand, I think that my life has been very interesting, I have experienced quite a lot. I have fulfilled my dreams. I have travelled quite a lot. (Magda has lived in the USA, UK and the Arab Emirates)

Social comparisons evoke the notion of 'normality' which can be considered a desirable goal and serve as a normative lens to defining what is acceptable in social life. If previous research on migration refers to normality, especially in the context of relative deprivation in postsocialist contexts (Manolova, 2019; McGhee et al., 2012; Polkowski, 2017), here, normality can also be analysed in the context of stasis versus flux. In such comparisons, normality and the specifics of a 'normal' life are subject both to controversy and discussion in the social experiences of migrants. Such controversy and discussion are the consequence of migration experience being normatively assessed both by those who move and those who do not move. Stayers tend to associate normality with the mundane, with everyday life, earning a living and fulfilling societal obligations. Migration experience, instead, is seen in opposition to being down to earth ("flying around"). Natalia, a woman in her late thirties, argues against this limited sense of what normality entails. She first builds the common ground for normality with stayers ("I also pay taxes"), going further and explaining how her normality is more challenging than living in the well-known context of the home country:

Sometimes people say this about emigrants, oh, you're just flying around etc. And a friend once said to me that this isn't a normal life. I said 'How come this isn't normal? I also pay taxes, I have to worry about electricity, gas, different things. How come this isn't a normal life?' Sometimes it's even more difficult than living in your own country. (Natalia has lived in the UK and France)

This discussion resonates with the on-going reflection on rootedness versus mobility and building normative narratives through "intersubjective deliberations of contrasting positionalities" (Ghorashi, 2017, p. 2428).

\subsection{Personal Aspirations or Imposed Frames of Reference?}

Natalia's case exemplifies how social comparisons were sometimes forced on individuals by their social environment. This points to the observation that reference frames were used more often concerning social networks and evaluations made by others than personal images of oneself. In particular, the informants reported evaluations made in the country of origin. Here, gender power dynamics also come into play (cf. Bivand Erdal \& Ryan, 2018) as it was especially women who perceived these comparisons as a burden, entailing negative pressure and related specifically to the Polish context, as opposed to the countries of migration. Krystyna, a woman in her fifties who started migrating after her second divorce, recalls a pressure related, inter alia, to physical appearance and signs of material status:

In Poland, you live under pressure. You live under pressure because your friend has had her hair done, she has a trendy haircut. Another one has had her lips done, for example, a third one has had something else, and you don't have all that and you feel unhappy and you feel that you stand out. (Krystyna has lived in Germany and two different African countries)

Joanna, another woman in her early thirties, reports on the process of her changing perspective through migration experience, when she ceases to compare herself to others in a material sense. As her geographical horizons widen, her comparative horizons diminish:

I come from a town where this mentality is a bit stupid, everyone is interested in everyone. I'm sure that a lot has changed in me, that I don't have this interest in someone's life, that he has this much and I want that much too, or that I would want to be better than him. And once it was like that, yes. I used to say: my friend has, I don't know, a nice job, I would like to have a job like that too, or she can afford something, I want that too. And now whatever I do, I do it for myself. Travelling has taught me that and the people that I have met in my life. (Joanna has lived in Italy and the USA)

But reflection can also go in the opposite direction, people met on the way can enhance comparisons that make you feel you are not as special as you previously thought when comparing to a different social environment. As in the case of other multiple migrants (see, e.g., Parreñas, 2015; Paul, 2017), Poles are often driven by aspirations of upward social mobility. However, depending on structural factors and power relations, the social position acquired in a new environment can be perceived either as promotion or degradation. In the latter case-which seems especially interesting in the analysis of migration narratives-such perceived degradation of social position may not necessarily refer to the material or occupational dimensions but to the value of acquired competences and resources that hold importance for social positioning and are appreciated in the actor's social networks, as in the case of Beata, a woman now in her early forties, who first migrated many years ago: 
I knew English, I felt very good in it and I was so...you know in Poland I thought 'great,' right? In every country, I will be somebody. Whereas I came here and damn, the people I knew, each of them knew three languages. And again I was....I felt so little. My God, me with my poor English, people here jump from one language to another and I only have this one [language]-English. (Beata has lived in the UK and Germany)

The informants' narratives also included more conventional distinctions between different types of Polish migrants, as already described in existing literature (e.g., Burrell, 2009; Krings et al., 2013). Social class and migration motivations (lifestyle versus employment) were at the heart of how our informants distanced themselves from other Poles, also migrants. Such motives were especially visible when it came to highly skilled professionals, as opposed to lower-skilled economic migrants. But also those with lower social standing distinguished themselves from migrants driven by lifestyle motives. Similar mechanisms could occasionally be observed in the narratives of multiple migrants settled in their destination country concerning newly-arrived Poles. This can be related to cultural and symbolic class boundary-making, as described by Manolova (2020) in the Bulgarian case of negotiating class identification and status attributes in a post-transition context. According to her analysis, those aspiring for status achievement will be careful to distinguish themselves from the 'ordinary migrant' as opposing idealistic 'free movement' to regular 'migration' based on purely materialistic motives.

\subsection{Polish Multiple Migrants Situating Themselves within Regional and Global Power Dynamics}

Finally, some Polish multiple migrants use wider points of reference and comparisons that involve global power relations. Writing about intra-EU migration (albeit largely limited to movements within the 'old' EU), Favell (2008) referred to the concept of spiralism to describe the social ascent via international mobility from often peripheral areas to Eurocities, along with the lifestyle aspects of such migration. A more nuanced and specific theme that appeared in the narratives of Polish migrants wasparaphrasing one of our interviewees - the post-socialist complex juxtaposed against the 'imaginary West' (as conceptualised by Manolova, 2019, pp. 62-63). Poland, having a history of communist regime, is still to some extent perceived as developing economically, still on the track to stable prosperity. Along with this, it is characterised by more conservative and closed attitudes, where intolerance towards various groups is commonplace, as opposed to 'the West.' In this sense, migration itself provides for some interviewees the opportunity to enhance one's position and be part of a bigger European project or even a 'cosmopolitan elite,' which is perceived here as a specific identity, useful in status boundary work.
Mobility may thus give passage to entering a "superior symbolic collective" and a sense of belonging to western culture and citizenship (Manolova, 2020, p. 519). This echoes with the concept of 'escaping to' a place where self-expression and self-development, as well as the possibility to follow different cultural patterns, are perceived as more available, which exceeds other, more traditional migration motives (Kaźmierska et al., 2011, p. 149). As in the narratives of Andrzej (male), Dominika and Sylwia (both women), all in their thirties:

Well, it's no secret that I always had some complex of coming from Central Europe, because these are post-communist countries. And I wanted to see how it...how this West, this famous West really looks like, and live here for a bit and breathe this air. So apart from this career, these challenges and international career, it was this desire to sort of define myself as a Pole in this European project and understand what this parallel [to Polish] nationality is, I mean the European one....Although we have been functioning in it for 30 years, I still have the impression that we are in some kind of transformation phase, economic and...and social one, and probably also political, compared to the West. We are still less mature. (Andrzej has lived in Holland, Germany and Belgium)

I left [Poland] with this [thinking]...to get in line.... with these super attractive foreigners from the West, and not talk too much about how it is in our country. I think I kind of hid many things [then]. (Dominika has lived in Switzerland, Germany, Belgium, Russia)

There is this sort of international elite, which is international, cosmopolitan or whatever. And I simply joined it in a sense. Although I do not have the feeling of being submerged in the country I am in. (Sylwia has lived in Turkey and the UK)

Such narratives fit into the core-periphery framework, where motives of migrating to escalator regions, the engines of social climbing (see Fielding, 1993), are multi-dimensional, involving lifestyle, career and identity options as well (King et al., 2018). In this sense, countries of Western Europe and the USA are sometimes perceived and idealised in collective social images as lands of opportunity where a generalised 'other' can always make it (Kaźmierska et al., 2011; Manolova, 2019). Consequently, a Polish migrant's social position may at first be underprivileged but mobility in effect will lead to enhancing material and social status both in Poland and abroad. Paradoxically, this belief may also be perceived as a burden once the opportunity does not play out as anticipated, as in the personal experience of Marcin, a man in his mid-thirties:

You know, I think that Poles have this thing when it comes to America, that they have to succeed. They 
are very ashamed if something goes wrong. This shame is something that they feel, it's their inside problem more than something that others around can see looking at these people. It is our stupid Polish ambition that we are so sickly ambitious that we are afraid to admit to failure....Because everyone in America has to succeed. That's how I see it here. Everyone wants to show off the car they are driving, everyone wants to show off how well they are doing. You must succeed because this is America! You understand....Even when there was this whole stock market crash, everyone was saying how wonderful it is here. But that was not fully true. (Marcin has lived in the UK and the USA)

On the other end of such comparisons were countries perceived as underdeveloped, defined widely as the global South, in the context of global power relations. One interviewee purposely constructed Africa as a frame for comparison to place herself higher on a social scale of consumption and lifestyle. The process emphasised her privilege in Africa in opposition to her disadvantaged status in 'the West.' This obviously recreates some wider power dynamics where Central-Eastern European origin situates Polish migrants between two ends of the global continuum. Again, Krystyna's narrative can serve as an example here:

[In Africa] you can afford to take a plane, you fly where you want. You can afford to go on holiday. You can afford to buy cosmetics. You can afford to buy food....And I think this helps me, it is a plus, this kind of comparison. Because if in Europe you only see people who are better off, who [have] more than I do, then I feel so little, because I have nothing, right?

The excerpt above illustrates a theme present in recent migration literature concerning 'new' European migration. Polish migrants along with other 'new' Europeans should be seen as structurally and discursively embedded in historical power relations, where their position in social hierarchies, in relation to other migrant and host society groups, is often unequal (Lulle et al., 2019). In 'old' Europe or 'the West,' their position will often be deprived but when we expand the reference frame the perceived social status of these same people may quite automatically shift.

\section{Conclusion}

Polish multiple migrants constitute a relatively heterogeneous group in terms of resources, aspirations, and countries in which they have lived so far. What they have in common is a broader range of migration experiences in various locations than other mobile Poles. Focusing on narratives of Polish multiple migrants, we contribute to a call by Pries (2001) on a new research agenda on plurilocal transnational social fields. As we show, this multi- local perspective on migration challenges the sedentary ways of thinking diagnosed in migration and refugee research and criticised elsewhere (see de Haan, 1999; Ghorashi, 2017; Malkki, 1992; Scalettaris, 2007).

While literature on transnational social fields recognises that migrants can be engaged simultaneously in various contexts, empirical research tends to understand migrants as making comparisons between contexts of origin and destination (Piore, 1979; Waldinger \& Lichter, 2003). We broaden the bi-focal perspective, linking to existing research on social inequalities which enlists other possible frames for reference, including onward destinations and global scale (Faist \& Bilecen, 2015). In this article, we bring to the fore the non-sedentary aspect of migration and outline how the very experience of being mobile is used to construct comparisons concerning lifestyles and aspirations.

The place of origin can play different roles in these comparisons. On the one hand, it is only natural to compare with people left at the point of departure. Still, these types of comparisons often describe a considerable detachment in the ways that lives are lived (see Favell, 2008) and evoke reflections around 'normality' (examined elsewhere in the context of migration research, see, e.g., Galasińska \& Kozłowska, 2009; McGhee et al., 2012). It is especially this notion of normality that provides an example of comparisons that migrants do not necessarily make themselves, but which are assigned to them by their social milieu-in particular by those settled at the place of origin, sometimes also including significant others. Both types of comparisons (produced by and forced on migrants) matter as they are brought up spontaneously when accounting their migration and life stories and experiences in the destination countries, as well as evaluating life choices and general satisfaction. The literature on repeated international migration involves many significant decisions along the way (see, e.g., Paul, 2017) and migrants sometimes reflected on what would have happened if they had taken another route, both geographically and individually, in their professional or personal life. This naturally induces comparisons with those whose decisions were different, to evaluate both actual and potential consequences.

Perhaps quite surprisingly, this research also documents how broader horizons of multiple migration can work in two opposite directions for those involved. On the one hand, multiple migrations expand the possible range of experiences and, thus, the frames of reference broaden as well (for a comparison with the literature on onward migrants see Paul, 2017; Wu \& Wilkes, 2017). In particular, Polish multiple migrants may position themselves against European and global perspectives. The post-socialist context may be seen as a burden, but not necessarily. Moreover, return migrants may discover that Poland has changed significantly since they first left the country. A need to compare with others may also be a reflection of the aspiration to position oneself 
higher on the social hierarchy, like in the case of comparisons between different countries. On the other hand, another outcome of these diverse and multiple experiences can be that migrants no longer feel the need to compare themselves at all. This is the case when individuals consider the act of social comparing as a manifestation of a backward, small-town mentality, which they claim to have lost on their migrant journey.

Comparisons that appear in the narratives of Polish multiple migrants make the substantive topic of this article. Analytically, the research on which this article is based does not have a comparative group (e.g., stayers in Poland, one-off migrants). However, where possible, we make use of internal comparisons within the sample, making distinctions between the different groups of multiple migrants holding various sets of resources (assigned and achieved) and also geographical locations of migration. The fact that we focus on one case only, with Polish migrants as a single migrant group in this analysis, is a limitation of our research. Future research could address these points by expanding the focus on highly mobile individuals in general. While this study highlights selected links between repeated international migration directed at various destinations and social comparison, we are still missing the quantified picture. Also, more extensive qualitative research could address a wider range of migrant groups, with a more systematic selection of destinations in an attempt to understand these processes in comparative perspective.

\section{Acknowledgments}

This article is based on data collected in the research project "In Search of a Theory of Multiple Migration. A Quantitative and Qualitative Study of Polish Migrants after 1989" (ID No. 2015/18/E/HS4/00497), funded by the National Science Centre in Poland (Sonata BIS). We acknowledge valuable comments from Marta Kluszczyńska and Aneta Krzyworzeka-Jelinowska. We are most grateful for constructive feedback from three anonymous reviewers.

\section{Conflict of Interests}

The authors declare no conflict of interests.

\section{References}

Beaverstock, J. V. (2005). Transnational elites in the city: British highly-skilled inter-company transferees in New York City's financial district. Journal of Ethnic and Migration Studies, 31(2), 245-268. https:// doi.org/10.1080/1369183042000339918

Bell, J. (2016). Migrants: Keeping a foot in both worlds, or losing the ground beneath them? Transnationalism and integration as experienced in the everyday lives of Polish migrants in Belfast, Northern Ireland. Social Identities, 22(1), 80-94. https://doi.org/

\subsection{0/13504630.2015.1110359}

Bhachu, P. (1985). Twice migrants: East African Sikh settlers in Britain. London and New York, NY: Tavistock Publications.

Bivand Erdal, M., \& Ryan, L. (2018). Gendered, spatial and temporal approaches to Polish intra-European migration. Gender, Place \& Culture, 25(6), 843-849. https://doi.org/10.1080/0966369X.2018.1472068

Buchowski, M. (2006). The specter of Orientalism in Europe: From exotic other to stigmatized brother. Anthropological Quarterly, 79(3), 463-482. https:// doi.org/10.1353/anq.2006.0032

Burrell, K. (Ed.). (2009). Polish migration to the UK in the 'new' European Union after 2004. Farnham: Ashgate.

Burrell, K. (2011). Going steerage on Ryanair: Cultures of migrant air travel between Poland and the UK. Journal of Transport Geography, 19(5), 1023-1030. https://doi.org/10.1016/j.jtrangeo.2010.09.004

de Haan, A. (1999). Livelihoods and poverty: The role of migration-A critical review of the migration literature. Journal of Development Studies, 36(2), 1-47. https://doi.org/10.1080/00220389908422619

Drinkwater, S., \& Garapich, M. P. (2015). Migration strategies of Polish migrants: Do they have any at all? Journal of Ethnic and Migration Studies, 41(12), 1909-1931. https://doi.org/10.1080/1369183X. 2015.1027180

Engbersen, G., Snel, E., \& de Boom, J. (2010). “A van full of Poles": Liquid migration from Central and Eastern Europe. In R. Black, G. Engbersen, M. Okólski, \& C. Panţîru (Eds.), A continent moving West? EU enlargement and labour migration from Central and Eastern Europe (pp. 115-140). Amsterdam: Amsterdam University Press.

Faist, T., \& Bilecen, B. (2015). Social inequalities through the lens of social protection: Notes on the transnational social question. Population, Space and Place, 21(3), 282-293. https://doi.org/10.1002/psp.1879

Faist, T. (2014). 'We are all transnationals now': The relevance of transnationality for understanding social inequalities (COMCAD Working Paper No. 122). Bielefeld: Centre on Migration, Citizenship and Development (COMCAD), Faculty of Sociology, Bielefeld University.

Favell, A. (Ed.). (2008). Eurostars and Eurocities. Oxford: Blackwell Publishing.

Fielding, A. (1993). Mass migration and economic restructuring. In R. King (Ed.), Mass migration in Europe: The legacy and the future (pp. 5-18). London: Belhaven Pinter.

Galasińska, A., \& Kozłowska, O. (2009). Discourses of a "normal life" among post-accession migrants from Poland to Britain. In K. Burrell (Ed.), Polish migration to the UK in the 'new' European Union after 2004 (pp. 87-106). Farnham: Ashgate.

Ghorashi, H. (2017). Negotiating belonging beyond rootedness: Unsettling the sedentary bias in the Dutch culturalist discourse. Ethnic and Racial Stud- 
ies, 40(14), 2426-2443. https://doi.org/10.1080/ 01419870.2016 .1248462

Górny, A., \& Kindler, M. (2016). The temporary nature of Ukrainian migration: Definitions, determinants and consequences. In O. Fedyuk \& M. Kindler (Eds.), Ukrainian migration to the European Union: Lessons from migration studies (pp. 91-112). Berlin: Springer International Publishing.

Grabowska-Lusińska, I., \& Okólski, M. (2009). Emigracja Ostatnia? [Ultimate emigration?] Warsaw: Wydawnictwo Naukowe Scholar.

Grzymala-Kazlowska, A., \& Phillimore, J. (2019). Superdiversity and its relevance for Central and Eastern European migration studies. The case of Polish migrants in the UK. Central and Eastern European Migration Review, 8(2), 39-59. https://doi.org/10.17467/ ceemr.2019.16

Hugo, G. (2008). In and out of Australia: Rethinking Chinese and Indian skilled migration to Australia. Asian Population Studies, 4(3), 267-291. https://doi.org/ 10.1080/17441730802496508

Kaźmierska, K., Piotrowski, A., \& Waniek, K. (2011). Biographical consequences of working abroad in the context of European mental space. Sociological Review, 1, 139-158.

King, R., Lulle, A., Parutis, V., \& Saar, M. (2018). From peripheral region to escalator region in Europe: Young Baltic graduates in London. European Urban and Regional Studies, 25(3), 284-299. https://doi. org/10.1177/0969776417702690

Krings, T., Moriarty, E., Wickham, J., Bobek, A., \& Salamońska, J. (2013). New mobilities in Europe: Polish migration to Ireland post-2004 (1st ed.). Manchester: Manchester University Press.

Levitt, P., \& Glick Schiller, N. (2004). Conceptualizing simultaneity: A transnational social field perspective on society. International Migration Review, 38(3), 1002-1039. https://doi.org/10.1111/j.17477379.2004.tb00227.x

Lulle, A., King, R., Dvorakova, V., \& Szkudlarek, A. (2019). Between disruptions and connections: "New" European Union migrants in the United Kingdom before and after the Brexit. Population, Space and Place, 25(1). https://doi.org/10.1002/psp.2200

Malkki, L. (1992). National geographic: The rooting of peoples and the territorialization of national identity among scholars and refugees. Cultural Anthropology, 7(1), 24-44.

Manolova, P. (2019). "Going to the West is my last chance to get a normal life": Bulgarian would-be migrants' imaginings of life in the UK. Central and Eastern European Migration Review, 8(2), 61-83. https://doi.org/10.17467/ceemr.2018.01

Manolova, P. (2020). Aspiring, ambivalent, assertive: Bulgarian middle-class subjectivities and boundary work through migration. East European Politics and Societies: And Cultures, 34(2), 505-528. https://doi.org/ $10.1177 / 0888325419837349$
McGhee, D., Heath, S., \& Trevena, P. (2012). Dignity, happiness and being able to live a "normal life" in the UK-An examination of post-accession Polish migrants. Transnational autobiographical fields. Social Identities, 18(6), 711-727. https://doi.org/ 10.1080/13504630.2012.709002

Moret, J. (2017). Mobility capital: Somali migrants' trajectories of (im)mobilities and the negotiation of social inequalities across borders. Geoforum. https://doi. org/10.1016/j.geoforum.2017.12.002

Nowicka, M. (2013). Positioning strategies of Polish entrepreneurs in Germany: Transnationalizing Bourdieu's notion of capital. International Sociology, 28(1), 29-47. https://doi.org/10.1177/ 0268580912468919

Parreñas, R. S. (2015). Servants of globalization: Migration and domestic work (2nd ed.). Stanford, CA: Stanford University Press.

Paul, A. M. (2017). Multinational maids: Stepwise migration in a global labor market. Cambridge: Cambridge University Press.

Piore, M. J. (1979). Birds of passage: Migrant labor and industrial societies (1st ed.). Cambridge: Cambridge University Press.

Polkowski, R. (2017). Normality unpacked: Migration, ethnicity and local structure of feeling among Polish migrant workers in Northern Ireland with a comparative perspective on Scotland. Journal of Ethnic and Migration Studies, 43(15), 2519-2535. https:// doi.org/10.1080/1369183X.2017.1299621

Pries, L. (Ed.). (2001). New transnational social spaces: International migration and transnational companies in the early twenty-first century. London and New York, NY: Routledge.

Salamońska, J. (2017). Multiple migration: Researching the multiple temporalities and spatialities of migration (CMR Working Paper 102/160). Warsaw: Centre of Migration Research, University of Warsaw.

Scalettaris, G. (2007). Refugee studies and the international refugee regime: $A$ reflection on a desirable separation. Refugee Survey Quarterly, 26(3), 36-50. https://doi.org/10.1093/rsq/hdi0241

Sheller, M., \& Urry, J. (2006). The new mobilities paradigm. Environment and Planning A: Economy and Space, 38(2), 207-226. https://doi.org/10.1068/ a37268

Urry, J. (2000). Sociology beyond societies: Mobilities for the twenty-first century. London and New York, NY: Routledge.

Waldinger, R. D., \& Lichter, M. I. (2003). How the other half works: Immigration and the social organization of labor. Berkeley, CA: University of California Press.

White, J. (2012). Parallel lives: Social comparison across national boundaries. (LSE 'Europe in Question' Discussion Paper No. 47/2012). London: The London School of Economics and Political Science.

Williams, A. M., \& Hall, C. M. (2000). Tourism and migration: New relationships between production and con- 
sumption. Tourism Geographies, 2(1), 5-27. https:// doi.org/10.1080/146166800363420

Williams, A. M., Chaban, N., \& Holland, M. (2011). The circular international migration of New Zealanders: Enfolded mobilities and relational places. Mobilities, 6(1), 125-147. https://doi.org/10.1080/17450101. 2011.532659

Winiarska, A. (2017). Qualitative longitudinal research:
Application, potentials and challenges in the context of migration research (CMR Working Paper 103/161). Warsaw: Centre of Migration Research, University of Warsaw.

Wu, C., \& Wilkes, R. (2017). 'International students' post-graduation migration plans and the search for home. Geoforum. https://doi.org/10.1016/ j.geoforum.2017.01.015

\section{About the Authors}

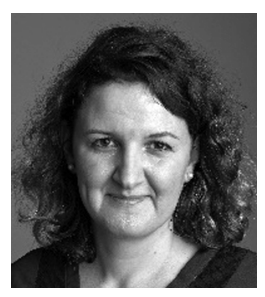

Justyna Salamońska is Assistant Professor at the Centre of Migration Research, University of Warsaw, and Principal Investigator in the MULTIMIG project. She holds a PhD in Sociology from Trinity College Dublin. She previously carried out research and taught at Trinity College Dublin, at the University of Chieti and in the European University Institute. Her research and teaching interests include contemporary migrations in Europe, multiple migrations, migrant labour market integration, cross-border mobilities, quantitative and qualitative research methods.

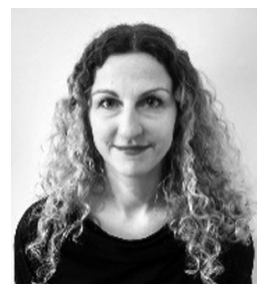

Aleksandra Winiarska is Assistant Professor at the Institute of Applied Social Sciences, University of Warsaw, and Associate Researcher at the Centre of Migration Research, University of Warsaw. She holds a PhD in Sociology. She has previously cooperated as a researcher with the University of Sheffield and the Medical University of Warsaw in projects concerning diversity, migration and integration. Her academic interests include social encounters, intercultural communication and socio-cultural processes related to migration. 